\title{
Fish Marketing System and Socio Economic Status of Aratdars in Natore and Rajshahi, Bangladesh
}

\author{
F. A. Flowra, A. H. M. K. Bashar, S. N. Jahan, M. A. Samad and M. M. Islam \\ Department of Fisheries, Rajshahi University, Rajshahi-6205 \\ Email:flowrabd@yahoo.com
}

\begin{abstract}
An investigation was carried out during the period from December 2007 to November 2008 to find out the fish marketing system and socio economic status of aratdars at Singra (Natore), Baneshwar and Puthia (Rajshahi). Four types of fishes were observed where maximum fishes $(70 \%)$ were come from the local area and rest $(30 \%)$ was come from outside of Bangladesh. Four types of marketing channel were identified and the commission agents usually earn about $3-4 \%$ commissions from the farmers. The highest landing was $388143.75 \mathrm{~kg} / \mathrm{yr}$ (Hypophthalmichthys molitrix in Shingra) whereas the lowest landing was $701.75 \mathrm{~kg} / \mathrm{yr}$ (Xenentodon cancila in Baneshwar). Price varied from $20.38 \pm 4.58$ (Chanda ranga in Baneshwar) to $190.17 \pm 27.33 \mathrm{Tk} / \mathrm{kg}$ (Clarias batrachus in Baneshwar). The average marketing cost and marketing margin varied from 91 to 128 $\mathrm{Tk} / \mathrm{day}$ and 17.75 to $28.25 \mathrm{Tk} / \mathrm{kg}$ in Baneshwar. Majority $(53.76 \%$ in Puthia to $74.99 \%$ in Baneshwar) aratdars were found to class I-X. Major secondary occupation of the aratdars was fish farming (50\% in Puthia to $75 \%$ in Baneshwar). Most of the aratdars (75\% in Baneshwar and Shingra to 83\% in Puthia) were found to earn Tk 100-500 per day. Infrastructure of wholesale and retail fish markets were not adequate with regarding to sales area, packaging, sanitation, water supply, drainage, cleaning, washing, maintenance and repairs except very few.
\end{abstract}

Key words: Sources, transportation system, marketing channel, landing, pricing marketing cost, marketing margin, socio economic status

\begin{abstract}
Introduction
Marketing is defined as the business activities that involved in the flow of goods and services from the point of initial production until they reach the ultimate consumer. Fisheries marketing comprise all the activities and agencies conducting them, involved in the movement of fish or fish products from the farm or industries to the final consumers or end users. The fish marketing should not have the object only catching and selling of fish but the fish marketing should have the wide scope for exploitation production, distribution, preservation and transportation of fish in
\end{abstract}

addition actual sale of fish by reducing middlemen (Agarwal, 1990). Marketing provides the channel of communication between the producers and consumers which passes through a number of intermediaries: farias, beparies, retailers, and aratdars. Fish collectors commonly known as mohajons or aratders procure fish form the catchers, with the help of local brokers who get a profit margin or commission from the mohajons. The most serious marketing difficulties seem to occur in the remote communities, which lack of transport, ice, poor road facilities and where 
F. A. Flowra, A. H. M. K. Bashar, S. N. Jahan, M. A. Samad and M. M. Islam / Our Nature (2012) 10: 34-43

the farmers are in a particularly weak position in relation of intermediaries (Rahman, 1997). The successful fishery development of Bangladesh depends upon adequate consideration of biological, technical and economic information along with socio economic and cultural information for making an overall decision. Actually fresh fish marketing disorder not only seen in Bangladesh but also in Asian region (Shrivastava and Randhir, 1995). For this aim investigation of the social patterns, economic system and some related aspects of the people of fishery are found as the basic need. Afsaruddin (1964), Westerguard (1975-76) and Karim (1978) were focused on fishermen's occupation in the description of socio economic and socio-culture aspects. The fishermen are the producers of fish, but as a class they are extremely ignored socially and exploited economically. So, it is necessary to know about the socio economic condition of intermediaries and fishermen for the development of marketing strategy and livelihood status of them. King (1997) reported that some fisher folk groups and NGO's have attempted to market their own fish or produce value added products and become more active in small-scale marketing development activities in India. Therefore the present studies were designed to found out the detailed account of marketing and the sustainable livelihood of the aratdars.

\section{Materials and Methods}

The study was carried out for a period of December 2007 to November 2008 for getting a details account of marketing system of Singra (Natore), Baneshwar and Puthia (Rajshahi) and also the socio economic status of aratdars of the fish markets. Physically market visit and questionnaire based interview methods were used for data collection. Following formula are used for the calculation of marketing margin -

$\mathrm{MM}=\mathrm{P}_{\mathrm{r}}=\mathrm{P}_{\mathrm{f}}$ (Where, $\mathrm{MM}=$ Marketing margin, $P_{r}=$ Retail price and $P_{f}=$ Farm price).

All the data are analyzed by using computer software Microsoft Excel.

\section{Results and discussion}

\section{Structure of fish market}

The structure of the market could be characterized by a situation of the presence of many buyers and sellers. There were 33 (Shingra), 13 (Baneshwar), 13 (Puthia) aratdars and 200 (Shingra), 70-100 (Baneshwar), 90-100 (Puthia) retailers in the studied market. A number of people also work with the traders as daily basis. Wholesales were held from 6:00 AM to 12:00 PM and retail markets were held from 9:00 AM to 5:00 PM. The infrastructure of wholesale and retail fish markets were not adequate with regarding to sales area, packaging, sanitation, water supply, drainage, cleaning, washing and maintenance and repairs except very few. Hossain and Uddin (1995) also reported the same constrains and infra structural status of the fish market. Panikkar and Sathiadas (1989) found that due to lack of infrastructure facilities the supply of fish at the landing centre is highly inelastic in Kerala, India.

\section{Sources, supply and other facilities}

A remarkable amount of caught fish from rivers, canals, beels, haors, ponds, swamps, 
F. A. Flowra, A. H. M. K. Bashar, S. N. Jahan, M. A. Samad and M. M. Islam / Our Nature (2012) 10: 34-43

floodplains and paddy fields were came to the fish markets of the North-West area by the interference of fishermen, faria, bepari or by wholesaler. Both culture and capture fisheries produce less which accounts for high prices of all fish species during dry season. Annual report of NFEP, 1995 were also same. The transportation system of fish from surveyed fish landing center are presented in fig. 1 .

After catching, fishes were transported in the market by different vehicles (train, bus, truck, pick-up, boats, tampoo, rickshaw, bullock cart, cycle, van, tomtom, thalagaree, and bhar). There was a connection between fish transportation and marketing. But it was unfortunate to all of us that were no organized transportation system in studied area. Rokeya et al. (1997) were found same problem in their region. For the packaging and preservation different kinds of bamboo baskets, plastic baskets, leaves, pulm trees and banana leafs, wooden boxes, polythene bag or plastic bag, earthen pot, aluminium can, drum, few aquatic vegetation were used for fresh fish and fishery products.

Ice was used as 1: 3 for transportation in case of Hilsa and exported fishes. The daily supplies of fishes in Baneshwar, Puthia and Shingra bazar are presented in fig. 2.

In Shingra fish market, most of the fishes $(70 \%)$ were come from the local area and rests $(30 \%)$ were come from outside (India and Myanmar). Siddque (2001) also found that in Mymensingh markets, fishes were imported from Myanmar and India. Especially Indian major carps are larger sizes.

\section{Marketing channel}

In the present study the marketing channel was traditional and remains in the hands of private traders and government have no role in this field. So, the price of the fish fluctuates of the different intermediaries: farias, beparies, retailers, and aratdars. Four to five intermediaries were present in fish marketing (Rahman, 2003; Yousuf, 2004; Gupta, 2004 and Thakur, 1974). The involvements of large percentage of the middleman and commission agents reduce benefit to the fish products (Ahmed et al., 1993 and Mazid, 1994). The commission agents usually earn about 3-4\% commissions from the farmers. So, the price of fish increases in every stage by $20-40 \%$. More or less results were found by Khanam et al., 2003. The fish marketing channel of different fish markets are presented in fig. 3 .

\section{Landing, pricing, marketing cost and marketing margin}

Among the three fish market the highest landing was $388143.75 \mathrm{~kg} / \mathrm{yr}$ (H. molitrix in Shingra) whereas the lowest landing was $701.75 \mathrm{~kg} / \mathrm{yr}$ (X. cancila in Baneshwar). The highest landing was found in Shingra because "Chalan beel" was situated in front of Shingra bazar, which is the main source of fish of Shingra bazar. The highest price was $190.17 \pm 27.33 \mathrm{Tk} / \mathrm{kg}$ (C. batrachus in Baneshwar) whereas the lowest price was $20.38 \pm 4.58 \mathrm{Tk} / \mathrm{kg}$ (C. ranga in Baneshwar). The price of small fishes and also other fishes varies according to the season of the year with marketing cost. Market price of fish was not always constant i. e. when the supplies of fishes were high then the price of fishes were dropped and when the 
F. A. Flowra, A. H. M. K. Bashar, S. N. Jahan, M. A. Samad and M. M. Islam / Our Nature (2012) 10: 34-43

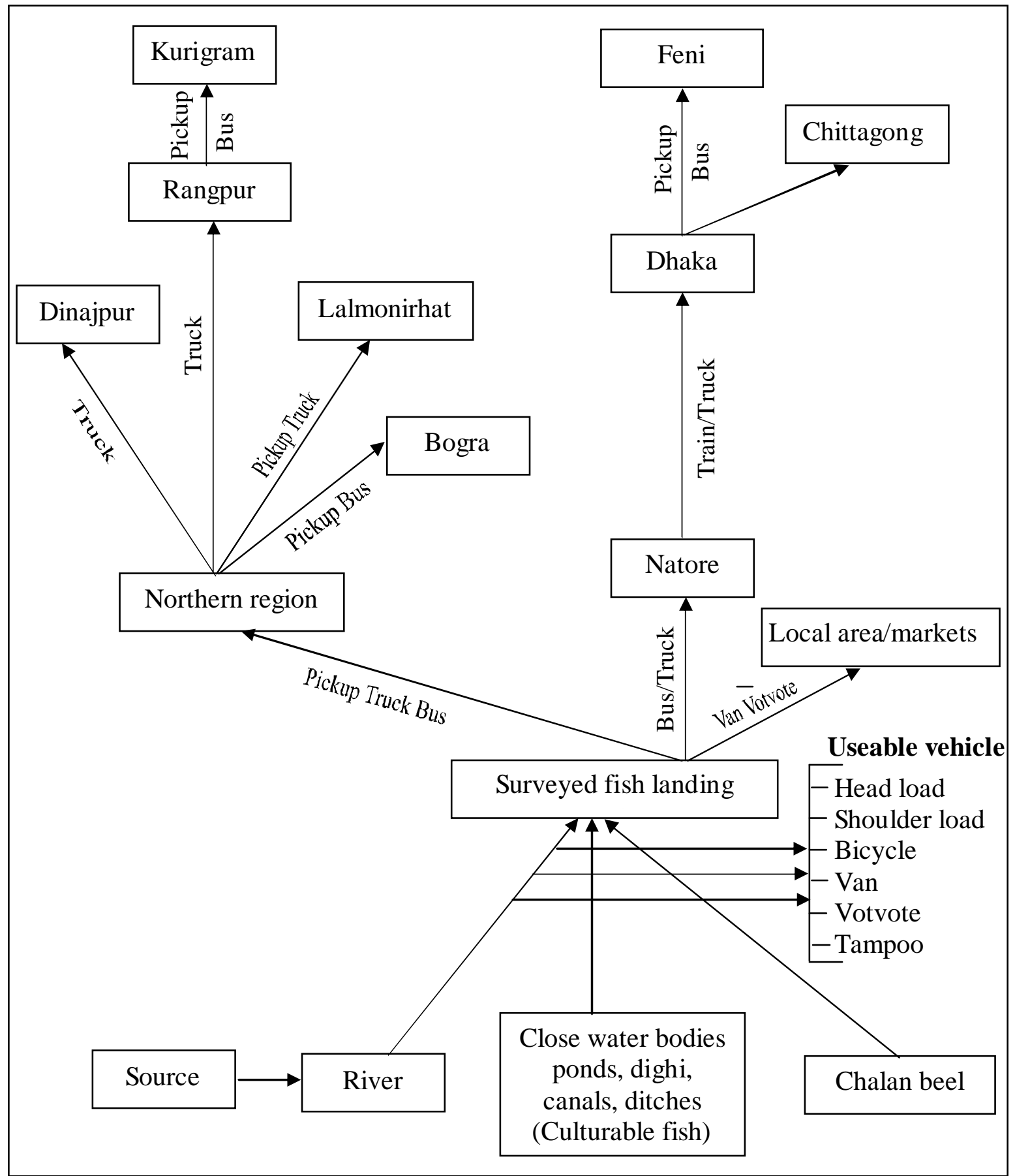

Figure 1. Showing the sources and transportation of fish from surveyed fish landing center 
F. A. Flowra, A. H. M. K. Bashar, S. N. Jahan, M. A. Samad and M. M. Islam / Our Nature (2012) 10: 34-43

supplies of fishes were low the price increase. Flowra et. al. (2000) worked on the relative importance of four commercial fishes and prawns of the North-West Region (NWR) of Bangladesh in relation to landing and price. Average landing and price of different fish species are presented in Table 1.
Yadov (1991) and Atapattu (1994) reported that fish growers association and co-operative organization should be established in order to aim at better production, harvesting and marketing. The average marketing cost varied from 91 to $128 \mathrm{Tk} /$ day in the surveyed markets. The highest total marketing cost was $8.00 \mathrm{Tk} / \mathrm{kg}$
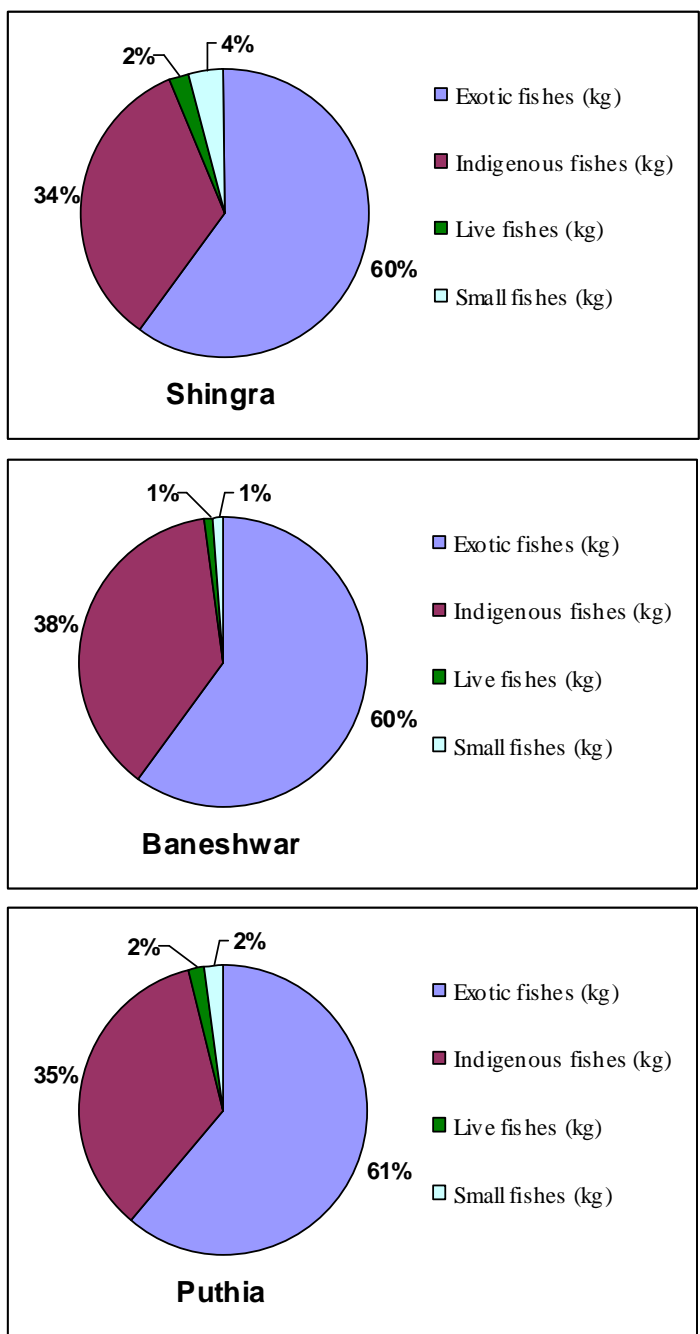

Figure 2. Supplies of fishes at different fish market 
F. A. Flowra, A. H. M. K. Bashar, S. N. Jahan, M. A. Samad and M. M. Islam / Our Nature (2012) 10: 34-43

for $C$. carpio (Shingra) and lowest was 4.50 $\mathrm{Tk} / \mathrm{kg}$ for $O$. nolotica (Baneshwar). The most sold fish species were $L$. rohita> $C$. catla> C. mrigala> H. molitrix> $P$. pangasius. The highest marketing margin of farias was found for L. rohita (Shingra). The highest marketing margin of beparies was found for L. rohita, $O$. nilotica and $C$. carpio (Baneshwar) whereas the lowest was found for $P$. sutchi (Baneshwar). Mia (1996); Khalil (1999); Biswas (2001); Rahman (2003); Gupta (2004) and Yousuf
(2004) were worked on market margin and price analysis. The highest margin price paid by consumers as Tk. $73.00 / \mathrm{kg}$ for $L$. rohita (Puthia). The fishermen get the maximum price for their commodity at Puthia fish landing center for $P$. sutchi which was Tk. $48.00 / \mathrm{kg}$ that was $73 \%$ of the consumer price. The lowest price obtained by the fishermen for $H$. molitrix was found as Tk. $25.00 / \mathrm{kg}$ at Shingra fish market at Natore.

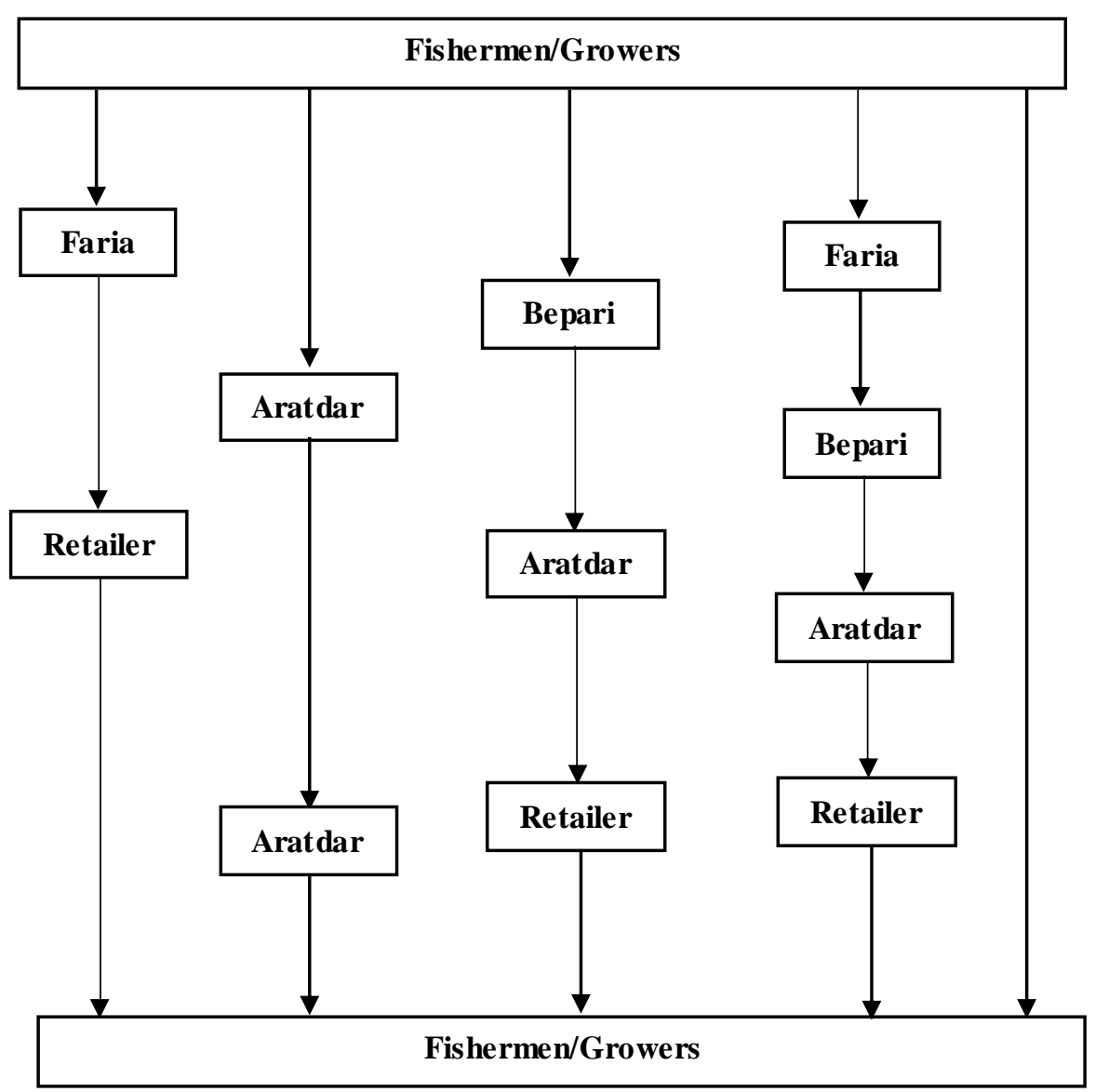

Figure 3. Showing the fish marketing channel 
F. A. Flowra, A. H. M. K. Bashar, S. N. Jahan, M. A. Samad and M. M. Islam / Our Nature (2012) 10: 34-43

Table 1. Average landing and price of different species in three fish markets

\begin{tabular}{|c|c|c|c|c|c|c|}
\hline \multirow[t]{2}{*}{ Different species } & \multicolumn{2}{|c|}{ Baneshwar } & \multicolumn{2}{|c|}{ Puthia } & \multicolumn{2}{|c|}{ Shingra } \\
\hline & $\begin{array}{c}\text { Landing } \\
\text { (kg/yr) }\end{array}$ & $\begin{array}{l}\text { Average price } \\
(\mathrm{Tk} / \mathrm{kg})\end{array}$ & $\begin{array}{c}\text { Landing } \\
\text { (kg/yr) }\end{array}$ & $\begin{array}{c}\text { Average price } \\
(\mathrm{Tk} / \mathrm{kg})\end{array}$ & $\begin{array}{c}\text { Landing } \\
\text { (kg/yr) }\end{array}$ & $\begin{array}{c}\text { Average price } \\
(\mathrm{Tk} / \mathrm{kg})\end{array}$ \\
\hline \multicolumn{7}{|l|}{ Exotic fishes } \\
\hline $\begin{array}{l}\text { Hypophthalmichthys } \\
\text { molitrix }\end{array}$ & 2846.41 & $40.35 \pm 1.18$ & 220023.00 & $39.49 \pm 0.09$ & 388143.75 & $38.55 \pm 1.32$ \\
\hline Aristichthys nobilis & 235115.75 & $39.84 \pm 2.81$ & 191986.25 & $39.88 \pm 0.85$ & 33233.25 & $38.10 \pm 1.85$ \\
\hline Cyprinus Carpio & 111049.00 & $51.18 \pm 5.54$ & 110167.25 & $53.13 \pm 2.70$ & 176815.75 & $49.97 \pm 4.12$ \\
\hline Cyprinus Carpio linnacus & 103062.50 & $49.16 \pm 7.76$ & 107125.00 & $52.07 \pm 3.47$ & 193082.00 & $48.68 \pm 4.61$ \\
\hline Ctenopharyngodon idellus & 226094.75 & $47.05 \pm 5.27$ & 192131.50 & $45.33 \pm 3.93$ & 298671.25 & $49.05 \pm 4.69$ \\
\hline Puntius gonionotus & 28887.28 & $36.88 \pm 7.92$ & 35112.50 & $45.07 \pm 17.66$ & 71938.50 & $40.70 \pm 7.82$ \\
\hline Oreochromis niloticus & 51761.30 & $41.52 \pm 9.67$ & 32106.00 & $41.09 \pm 11.10$ & 62554.50 & $39.20 \pm 7.54$ \\
\hline Clarias gariepinus & 47842.00 & $24.48 \pm 4.22$ & 13375.00 & $20.40 \pm 11.33$ & 35959.25 & $27.31 \pm 3.92$ \\
\hline Pangasius pangasius & 172811.00 & $50.53 \pm 14.06$ & 104618.25 & $53.44 \pm 3.09$ & 227379.50 & $49.11 \pm 12.83$ \\
\hline Tilapia mossumbicus & 19915.50 & $40.03 \pm 6.00$ & 23409.00 & $45.34 \pm 7.70$ & 55008.50 & $53.58 \pm 1.61$ \\
\hline Total & 999385.49 & & 1030053.75 & & 1839786.25 & \\
\hline \multicolumn{7}{|l|}{ Indigenous fishes } \\
\hline Labeo rohita & 209416.50 & $66.13 \pm 18.24$ & 173980.00 & $69.07 \pm 3.52$ & 256902.50 & $62.63 \pm 3.03$ \\
\hline Catla catla & 173146.25 & $72.05 \pm 6.86$ & 155803.75 & $71.37 \pm 4.58$ & 280249.25 & $65.22 \pm 3.31$ \\
\hline Cirrhinus mrigala & 166203.50 & $55.09 \pm 5.04$ & 164294.25 & $52.72 \pm 3.51$ & 277048.50 & $46.31 \pm 1.96$ \\
\hline Labeo calbasu & 24880.75 & $46.70 \pm 1349$ & 26633.25 & $51.19 \pm 17.86$ & 72862.75 & $59.05 \pm 4.47$ \\
\hline Labeo boga & 27055.00 & $54.78 \pm 5.77$ & 22124.25 & $54.08 \pm 15.05$ & 67093.25 & $60.18 \pm 2.23$ \\
\hline Chirrhinus reba & 19790.50 & $60.73 \pm 10.25$ & 20057.50 & $65.52 \pm 5.39$ & 58537.50 & $65.83 \pm 2.02$ \\
\hline Labeo bata & 10580.00 & $46.15 \pm 16.65$ & 14372.25 & $47.33 \pm 13.82$ & 48551.25 & $54.02 \pm 4.96$ \\
\hline Total & 631072.5 & & 577265.25 & & 1061245.00 & \\
\hline \multicolumn{7}{|l|}{ Live fishes } \\
\hline Heteropneustes fossilis & 1907.25 & $80.21 \pm 35.98$ & 2712.25 & $99.73 \pm 40.74$ & 14953.25 & $117.30 \pm 18.33$ \\
\hline Clarias batrachus & 2137.75 & $190.17 \pm 27.33$ & 3348.00 & $120.15 \pm 23.30$ & 12816.00 & $134.71 \pm 16.22$ \\
\hline Ompok pabda & 1794.50 & $159.28 \pm 36.55$ & 1669.75 & $183.03 \pm 67.87$ & 6413.50 & $188.79 \pm 35.16$ \\
\hline Mystus vittatus & 1107.20 & $60.25 \pm 19.91$ & 1643.25 & $63.56 \pm 30.99$ & 5679.25 & $72.50 \pm 9.04$ \\
\hline Anabas testudineus & 849.00 & $93.44 \pm 38.64$ & 881.50 & $91.77 \pm 47.78$ & 4399.19 & $116.68 \pm 16.48$ \\
\hline Chanjna striatus & 937.25 & $38.55 \pm 30.72$ & 1873.75 & $44.57 \pm 37.97$ & 4271.15 & $64.10 \pm 14.45$ \\
\hline Channa punctatus & 2724.75 & $25.92 \pm 5.27$ & 13939.50 & $29.65 \pm 3.61$ & 5295.75 & $31.62 \pm 5.70$ \\
\hline Total & 11457.7 & & 26068 & & 53828.09 & \\
\hline \multicolumn{7}{|l|}{ SIS } \\
\hline Puntius sophere & 4773.75 & $26.61 \pm 2.65$ & 7513.75 & $27.57 \pm 5.03$ & 4641.75 & $26.37 \pm 3.87$ \\
\hline Rasbora daniconius & 1442.75 & $20.55 \pm 10.27$ & 1816.50 & $25.08 \pm 2.24$ & 11702.50 & $28.32 \pm 2.62$ \\
\hline Amblypharyngodon mola & 2563.50 & $54.28 \pm 12.62$ & 4653.75 & $58.96 \pm 8.38$ & 11109.75 & $52.05 \pm 5.39$ \\
\hline $\begin{array}{l}\text { Pseudeutropius } \\
\text { atherinoides }\end{array}$ & 1544.25 & $46.49 \pm 23.72$ & 1703.50 & $62.00 \pm 11.95$ & 7998.75 & $52.46 \pm 18.05$ \\
\hline Salmostoma bacaila & 2521.75 & $50.11 \pm 17.37$ & 4379.75 & $54.73 \pm 8.88$ & 14310.50 & $55.38 \pm 4.08$ \\
\hline Chanda ranga & 2403.00 & $20.38 \pm 4.58$ & 4604.75 & $21.37 \pm 3.00$ & 19344.25 & $21.37 \pm 3.00$ \\
\hline Glossogobius giuris & 2032.75 & $32.40 \pm 4.63$ & 3510.00 & $33.9 \pm 55.49$ & 9973.50 & $35.44 \pm 3.39$ \\
\hline Xenentodon cancila & 701.75 & $25.53 \pm 13.85$ & 789.00 & $26.00 \pm 16.89$ & 3578.50 & $34.66 \pm 12.34$ \\
\hline Total & 17983.5 & & 28971.00 & & 124429.75 & \\
\hline
\end{tabular}


F. A. Flowra, A. H. M. K. Bashar, S. N. Jahan, M. A. Samad and M. M. Islam / Our Nature (2012) 10: 34-43

Table 2. Socio economic status of aratdars of different fish center at Rajshahi and Natore

\begin{tabular}{|c|c|c|c|}
\hline \multirow[t]{2}{*}{ Items } & \multicolumn{3}{|c|}{ Different bazar } \\
\hline & Baneshwar (\%) & Puthia (\%) & Shingra (\%) \\
\hline \multicolumn{4}{|l|}{ Family size (No.) } \\
\hline $3-5$ & 16.66 & 7.69 & 6.06 \\
\hline $6-7$ & 16.16 & 23.07 & 36.36 \\
\hline $8-9$ & 25.00 & 30.76 & 36.36 \\
\hline 10-Above & 41.66 & 38.46 & 21.21 \\
\hline \multicolumn{4}{|l|}{ Educational status } \\
\hline Illiterate & 8.33 & 7.09 & 18.18 \\
\hline Class I-V & 16.66 & 23.07 & 21.21 \\
\hline Class VI-X & 58.33 & 30.76 & 51.51 \\
\hline Class XI-Degree & 16.66 & 38.46 & 9.09 \\
\hline \multicolumn{4}{|c|}{ Health service (used by aratders) } \\
\hline Village doctor & 100 & 83.34 & 91.66 \\
\hline Community hospital & 16.66 & 8.33 & 25 \\
\hline Upazilla hospital & 0 & 16.66 & 33.33 \\
\hline District hospital & 8.33 & 25 & 16.66 \\
\hline Private clinic & 16.66 & 16.66 & 25 \\
\hline \multicolumn{4}{|l|}{ Other profession } \\
\hline Fish farmer & 75.00 & 50.00 & 58.66 \\
\hline Business & 16.66 & 16.67 & 25.00 \\
\hline Agriculture & 8.34 & 33.33 & 16.34 \\
\hline \multicolumn{4}{|l|}{ Daily income (Tk) } \\
\hline $100-500$ & 75.00 & 83.32 & 75.00 \\
\hline $500-900$ & 16.66 & 8.34 & 25.00 \\
\hline $900-1200$ & 8.34 & 8.34 & - \\
\hline \multicolumn{4}{|l|}{ Economic status } \\
\hline Lower middle class & 16.67 & 41.67 & 25.00 \\
\hline Middle class & 58.33 & 33.33 & 50.00 \\
\hline Rich & 25.00 & 25.00 & 25.00 \\
\hline
\end{tabular}

\section{Socio economic status}

The socio economic condition of aratders and other fish traders were still at and primary stage of growth in studied area (Table 2). Aratders of surveyed fish landing centers are poor, illiterate, few and follow the traditional fish business. Mia (1996) found that most of the fish traders were up to secondary level of education. It is true that the aratders also involved with other business and maintain rich livelihood. Some workers like Afsaruddin (1964), Westerguard (1975-76), Karim (1978) discussed on fishermen and fish trader's occupation in the description of socio economic and socio culture aspects. The information on the socio economic status of the fishermen, aratders and other fish traders will be helpful for making any development decision for North-West (Rajshahi and Natore) fish market and other fisheries sector.

\section{Conclusion and recommendation}

Almost all the aratdars were facing many problems and going through a very vulnerable livelihood. Low income (with daily and seasonal variation) was the most 
F. A. Flowra, A. H. M. K. Bashar, S. N. Jahan, M. A. Samad and M. M. Islam / Our Nature (2012) 10: 34-43

common and severe. In most cases there was no auction sheds, packing sheds, even proper drainage and hygienic facilities. Unauthorized intruders (Mastan), credit, lack of workers, undeveloped communication etc. were the main constrains of the aratdars. Among others, lack of capital, very poor or no preservation and processing facilities, pricing system, poor educational background and health service were also important. From the above point of view it may be concluded that the present over all declining fisheries status and little improved marketing system of surveyed fish landing center and market at Rajshahi and Natore was not satisfactory. The socio economic status of aratders was very average. Some recommendation for improving existing marketing system that affect on the food, nutrition as well as export earnings are a) Establish conservation area for fishes, b) Ensure better marketing and distribution of fishes, c) Improve season based modern storage system, d) Maintain sanitation and hygienic conditions in the fish markets, e) introduction of modern wholesaling and retailing facilities, e) Keep the constant price of fish by government g) Establish the documentation of the contribution of fish to livelihood of aratdars, income and nutrition in rural areas.

\section{Acknowledgements}

The authors are thankful to the personnel's of District Fishery Office of Rajshahi and Natore and also to all the traders, aratdars and other persons related to fish trading of the surveyed fish landing centre at Rajshahi and Natore for their cooperation in providing information.

\section{References}

Afsaruddin, M. 1964. Rural life in Bangladesh (A study of selected villages). New market, Dacca. $114 \mathrm{p}$.

Agarwal, S. C. 1990. Fishery management. Ashish Publishing House. 8/18, Punjabibagh, New Delhi-110026. 329-376 pp.

Ahmed, M., Rab, A. and Bimbao, M.P. 1993. Household socioeconomic, resource use and fish marketing in two thanas in Bangladesh. ICLARM Tech. Rep. 40-82 pp.

Atapattu, A.R 1994. Community-based approaches to fisheries management: the role of marketing development and fisheries co-operatives in improving socio-economic conditions of smallscale fishermen. In: Socio-economic Issues in Coastal Fisheries Management, Proceedings of the Indo-pacific Fishery Commission (IPIC) Symposium, Bangkok, Thailand, RAPA publ.8:281-286 pp.

Biswas, H. 2001. Dried marine fish marketing in greater Chittagong district. MS Thesis. Department of Co-operative and Marketing, Bangladesh Agricultural University, Mymensingh. $119 \mathrm{p}$.

Flowra, F. A., Hossain, M. A. and Parween, S. 2000. Relative importance of four commercial fishes and prawns of the North-West Region (NWR) of Bangladesh in relation to landing and price. $J$. bio-sci., $8: 57-60$.

Gupta, S. D. 2004. Status of Fish marketing in Fulpur Upazill, Mymensingh. M. S. Thesis. Department of Fisheries Management, Bangladesh Agricultural University, Mymensingh. 63 p.

Hossain, M. M. and Uddin, M. H. 1995. Quality control and marketing of fish and fish product needs for infrastructure and legal support. Paper presented in the National workshop of Fisheries Research Development and Management form 29 October to 10 November. Dacca. Bangladesh.

Karim, A. 1978. Socio-economic survey of village Sahapur. A project work submitted in the Dept. of Sociology. Rajshahi University. 48 p.

Khalil, M. I. 1999. Marine fish marketing in some selected areas of Bangladesh. MS Thesis.

Department of Co-operative and Marketing. Bangladesh Agricultural University. Mymensingh. $76 \mathrm{p}$.

Khanam, M. N. A., Ali, M. Z., Ali, M. M. and Hossain, M. A. R. 2003. Supply and marketing of small indigenous species of fish, and 
F. A. Flowra, A. H. M. K. Bashar, S. N. Jahan, M. A. Samad and M. M. Islam / Our Nature (2012) 10: 34-43

livelihood strategy of the retailers in a peri-urban fish market. 135-142 pp.

King, D. 1997. Fish Marketing. In : D. King (ed) Fish Marketing : no shortcuts to success. Newsletter of the post-harvest fisheries project. Issue no. $122 \mathrm{p}$.

Mazid, M. A. 1994. Proc. SAARC workshop on fisheries socioeconomics and marketing. BARK. Dhaka.

Mia, G. M. F. 1996. A study of production and marketing of culture fishes the selected pond owners in Mymensingh district. MS Thesis. Department of Co-operative and Marketing. Bangladesh Agricultural University. Mymensingh. 119 p.

NFEP, 1995. North- West Fisheries Extension Project, Parbatipur, Dinajpur. Annual Report. Season of the Extension and Training Section. 76-90 pp.

Panikkar, K. K. P. and Sathiadas, R. 1989. Marine fish marketing trend in Kerala. J. Mar Biol. Assoc. India, 31 (1-2): 239-246.

Rahman, A. K. A. 1997. Fish marketing in Bangladesh: Status and Issue. The University Press Ltd. Dhaka, Bangladesh. 99-114 pp.

Rahman, M. M. 2003. Status of Fish Marketing in Gazipur, Bangladesh. M. S. Thesis. Department of Fisheries management. Bangladesh Agricultural University. Mymensingh. 79 p.
Rokeya, J. A., Ahmed, S. S., Bhuiyan, A. S. and Alam, M. S. 1997. Marketing system of native and exotic major carps of Rajshahi District. Bangladesh J. Fish. 20(1-2):99-103 pp.

Shrivastava, R. S. M. and Randhir. 1995. Efficiency of fish marketing at Bhubaneshwar city of Orissa (India): some policy implications. Bangladesh. $J$. Agric Econs . 18(1): 89-97.

Siddque, M. A. 2001. A study on socio-economic status of fishermen and fish marketing system in Mymensingh district, Bangladesh. M. S. Thesis. Department of Fisheries Management. Bangladesh Agricultural University. Mymensingh. 66 p.

Thakur, D. S. 1974. Food grain Marketing Efficiency: A case study by Gujrat Ind. J. Agr. Econ. xxix (4). Oct-Dec. 61.74 pp.

Westerguard, K. 1975-76. Economic and social analysis of a village in Bangladesh. The director. Rural Development Academy. Bogra. 55 p.

Yadov, R. K. 1991. Fish production in Nepal: Problems and prospects: a case study of Krishnapar village panchayat of Siraha district. Nepal.

Yousuf, M. A. 2004. Status of Fish Marketing in Jamalpur, Bangladesh. M. S. Thesis. Department of Fisheries Management. Bangladesh Agricultural University. Mymensingh. 90 p. 